\title{
STORABILITY AND VIABILITY OF BIOFERTILIZER IN VARIOUS FORMULAS OF CARRIER AND PACKAGING
}

\author{
${ }^{1 *}$ Dian Indratmi, ${ }^{1}$ Aniek Iriany, ${ }^{1}$ Ali Ikhwan, ${ }^{1}$ Rafida Hafsah \\ ${ }^{1}$ Department of Agrotechnology, Faculty of Agriculture and Animal Husbandry, \\ Muhammadiyah Malang University, Malang 65144, East Java, Indonesia. \\ *Corresponding author
}

DOI: https://doi.org/10.51193/IJAER.2021.7502

Received: 22 Sep. 2021 / Accepted: 29 Sep. 2021 / Published: 05 Oct. 2021

\begin{abstract}
Biofertilizers can be formulated in liquid or granular form. The advantages of biofertilizers in granular form are easy application and distribution. The active ingredients of biofertilizers are mainly in the form of a consortium of rhizobacteria or single rhizobacteria. The manufacture of granule biofertilizer requires the addition of several materials as a carrier medium. The carrier medium has the function of packing, and prolonging the storage time of the bacterial inoculum. Packaging has an important function to protect the rhizobacteria inoculum. The aim of the study was to determine the best carrier media formula and packaging, in order to increase the shelf life and viability of biofertilizers. The study used a factorial randomized block design, 2 factors with 3 replications. Factor I: carrier material formula, consisting of: Peat; Husk Charcoal; Husk charcoal + Kaolin (2:1); Peat+Kaolin (2:1); and Husk Charcoal+Peat+Kaolin (2:2:1). Factor II: type of packaging, consisting of plastic packaging and aluminum foil. Observations included total plate count, water absorption, dispersion time, density value and granule morphology. The results showed that the population of rhizobacteria in the carrier formula of husk charcoal with aluminum foil packaging was able to maintain viability and increase the shelf life of biofertilizers. The population of rhizobacteria at 4 months of storage was $\log _{10} 7.62 \mathrm{cfu} / \mathrm{g}(4.58 \mathrm{x}$ $10^{7} \mathrm{cfu} / \mathrm{g}$ ) (high population category). Biofertilizer in the form of granules with a carrier formula of husk charcoal has the highest absorption, fastest disintegration time, low density value, thick black morphology, and weak texture.
\end{abstract}

Keywords: Rhizobacteria, Shelf life, Total Plate Count, Viability 


\section{International Journal of Agriculture and Environmental Research}

ISSN: 2455-6939

Volume: 07, Issue: 05 "September-October 2021"

\section{INTRODUCTION}

Biofertilizers are fertilizers that contain microbes and are beneficial for plant growth such as nutrients in the soil. The quality standards of biofertilizers have certain conditions that must be met so that the microbes contained in biofertilizers have a positive influence on plants. Biofertilizers can be formulated in liquid or granule form. Advantages in the form of granules are improving the appearance, packaging of products, as well as reducing overdoses in the plant (Wardhani et al., 2020). Biofertilizers in liquid form have the benefit of more easily absorbing the soil because the content of the elements contained in it is fast and easily absorbed (Rahayu, 2017). Based on their active ingredients, biofertilizers have various types of active ingredients, one of which is rhizobacteria. Rhizobacteria bio-fertilizer is obtained from the rooting of the plant's rhizosphere. The wide zone is about $1 \mathrm{~mm}$ around the plant from various potential locations so that it can be applied in the field (Jha and Saraf, 2014). The manufacture of rhizobacteria biofertilizer requires a carrier medium so that the fertilizer can be formed into granules. Carrier media has the function of packing, growing, and extending the shelf life of bacterial inoculums (Firdausi et al., 2016). Carrier media must contain important components that can maintain the viability and growth of microbes. Compositions that can be used in carrier media include peat, husks charcoal, and kaolin. These three materials have different textures, surfaces, and contents that can bind inoculums to biofertilizers. The three carrier materials are carried out in the best combination experiment so that they can be applied. The application of rhizobacteria bio-fertilizer is certainly not done at one time, so it takes packaging that can store the fertilizer products.

The importance of packaging as a function to protect biofertilizers can maintain these qualities. Bio-fertilizer packaging serves as a material for protection, delivery, and presentation to manufacturers such as metals (aluminum foil and laminate film), and plastics (polyethylene, polypropylene, polyolefin, and polyester) (Arpitha and Brahmaprakash, 2016). Packaging problems in keeping the active ingredient rhizobacteria so as not to be contaminated and maintain shelf life and viability. Good shelf life has an impact on the viability of biofertilizers so that a combination of testing on the type of carrier and packaging materials can be done. The right combination of carrier and packaging materials can maintain their effectiveness as a biological fertilizer over a long period. The purpose of this study is to know the best carrier and packaging media to increase the shelf life and viability of biofertilizers.

\section{METHODS}

The research was conducted in November 2020 - April 2021 at the "Terpadu Laboratory" of the Faculty of Agriculture-Animal Husbandry, University of Muhammadiyah Malang. The study used a factorial randomized block design, repeated 3 times. The factor I is the type of carrier 


\section{International Journal of Agriculture and Environmental Research}

ISSN: 2455-6939

Volume: 07, Issue: 05 "September-October 2021"

medium, consisting of $\mathrm{C}_{1}$ : Peat, $\mathrm{C}_{2}$ : Husks charcoal, $\mathrm{C}_{3}$ : Husk charcoal + Kaolin $(2: 1)$; $\mathrm{C}_{4}$ : Peat + Kaolin (2:1), and $\mathrm{C}_{5}$ : husk charcoal + Peat + Kaolin (2:2:1). Factor II is a type of packaging consisting of $\mathrm{K}_{\mathrm{P}}$ : Plastic Packaging, and $\mathrm{K}_{\mathrm{A}}$ : Aluminum Foil Packaging. Research procedures with the preparation of rhizobacteria inoculum include $250 \mathrm{ml}$ stater that has been shaker for 1 day, molasses $500 \mathrm{ml}$, green growmore 10 grams, red growmore 10 grams, $\mathrm{NaCl} 58.5$ grams. The whole ingredient is mixed and shaker. The second stage with the preparation of carrying materials in granule biofertilizers used is peat, husk charcoal, and kaolin. Husk charcoal and peat are first ground with a grinding machine. The three materials are weighed according to the combination of treatments, inserted plastic for sterilization with an autoclave machine temperature of $121^{\circ} \mathrm{C}$ for 15 minutes. The granulation process is done by inserting little by little inoculum and granulating process until granules are formed. The packaging process is carried out when granule bio-fertilizer has dried and put on the packaging of 100 grams following the treatment of the combination of carrier and packaging types. The first granule bio-fertilizer observation variable, the viability of the Total Plate Count (TPC) method, is carried out every 2 weeks. Preliminary research in the form of observations of surface morphology on each granulecarrying material. The trick, by documenting the appearance of granules and identified them. Density value is done by weighing the mass of fertilizer divided by the volume of fertilizer beaker glass $250 \mathrm{ml}$, observations are made starting week 0 . The sample of biofertilizers was weighed 1 gram, diluted with a stratified dilution using $0.8 \%$ physiological salts, and inoculated as much as $100 \mu$ in sodium media in petri dishes with spread plate methods and flattened with $\mathrm{L}$ glasses. Petri dishes that have been inoculated bacteria included for \pm 18 hours and calculated the average number of cfu/gram colony-forming units. Observation of water absorption is done by soaking a 5-gram granule with water covered for 1 hour, filtered and placed on a cup, put in the oven, cool the sample for \pm 5 minutes, and weighed. Calculation of the absorption of water granules is calculated by formula Absorp of Water $=\frac{m b-m k}{m b} \times 100 \%$ Disperse time is done by weighing a sample of granule fertilizer weighing 5 grams into a beaker glass containing 100 $\mathrm{ml}$ of water, rest it for a while and record the time of the destruction of granule fertilizer is done with the 0th week of storage and the 16th week of storage of biological fertilizer, if during the storage of biological fertilizer there are microorganisms warehouse, observations are made. The research data was analysed with a variety analysis and continued with a 5\% Duncan (DMRT) test.

\section{RESULTS AND DISCUSSION}

\section{a. Total Plate Count $(\log 10$ cfu/grams)}

The results showed the storage of biofertilizers in various formulas of carrier materials and packaging determines the viability of microbes contained in granule biofertilizers (Figure 1.) 
International Journal of Agriculture and Environmental Research

ISSN: 2455-6939

Volume: 07, Issue: 05 "September-October 2021"

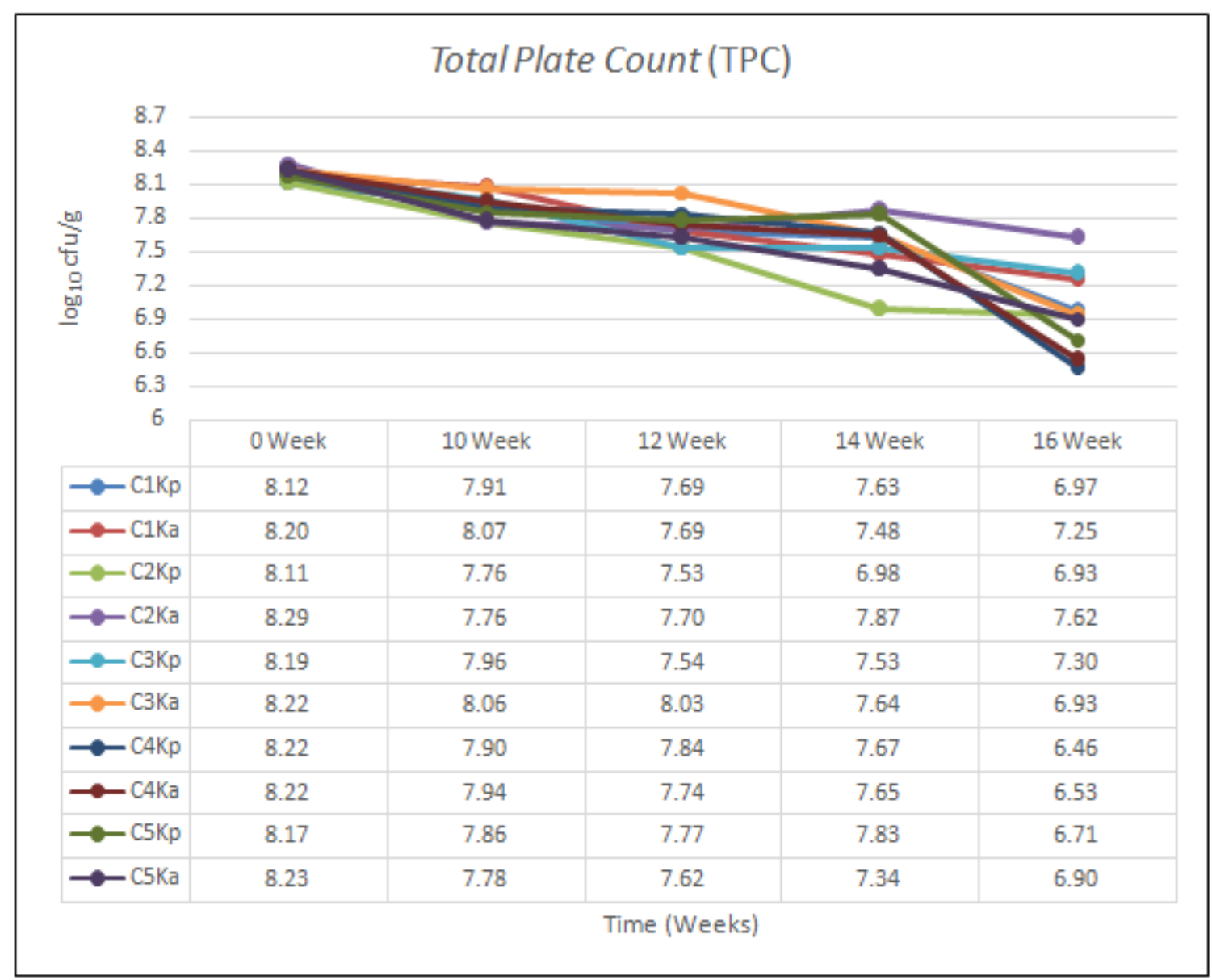

Fig. 1: Average Total Plate Count (TPC) Granule Biofertilizer for 16 weeks of storage

Description: $\mathrm{C}_{1} \mathrm{~K}_{\mathrm{p}}=$ Peat Plastic Packaging; $\mathrm{C}_{1} \mathrm{~K}_{\mathrm{a}}=$ Peat Aluminum Foil Packaging; $\mathrm{C}_{2} \mathrm{~K}_{\mathrm{p}}=$ Charcoal Husk Plastic Packaging; $\mathrm{C}_{2} \mathrm{~K}_{\mathrm{a}}=$ Charcoal Husk Aluminum Foil Packaging; $\mathrm{C}_{3} \mathrm{~K}_{\mathrm{p}}=$ HuskCharcoal + Kaolin Plastic Packaging; $\mathrm{C}_{3} \mathrm{~K}_{\mathrm{a}}=$ Huskcharcoal+Kaolin Aluminum Foil Packaging; $\mathrm{C}_{4} \mathrm{~K}_{\mathrm{p}}=$ Peat+Kaolin Plastic Packaging; $\mathrm{C}_{4} \mathrm{~K}_{\mathrm{a}}=$ Peat+Kaolin Aluminum Foil Packaging; $\mathrm{C}_{5} \mathrm{~K}_{\mathrm{p}}=$ Huskcharcoal +Peat+Kaolin Plastic Packaging; $\mathrm{C}_{5} \mathrm{~K}_{\mathrm{a}}=$ HuskCharcoal +Peat+Kaolin Aluminum Foil Packaging.

The viability of biofertilizers is calculated using the Total Plate Count. According to Tomasiewicz et al., (2021) colonies can be counted between 30-300 with units of cfu/gram or $\mathrm{cfu} / \mathrm{ml}$. The treatment of husk charcoal carrier formula with aluminum foil packaging in the initial storage has the highest value of $\log _{10} 8.29 \mathrm{cfu} / \mathrm{grams}\left(1.96 \times 10^{8} \mathrm{cfu} / \mathrm{grams}\right)$, while in the 16th-week storage obtained a $\log$ value of $\log _{10} 7.62$ cfu/grams (4.58 x $\left.10^{7} \mathrm{cfu} / \mathrm{grams}\right)$. According to the Regulation of the Indonesian Agricultural Government no. 70 / Permentan / SR.140 / 10/2011 on organic fertilizers, biofertilizers, and soil soils require a minimum limit of bacteria contained in biofertilizers with the type of solid carrier material or 
International Journal of Agriculture and Environmental Research

ISSN: 2455-6939

Volume: 07, Issue: 05 "September-October 2021"

granules have a density value of $\geq 10^{7} \mathrm{cfu} /$ grams. The limit of the quality of microbial control in culants in rhizobium biofertilizer granule form i.e. has a minimum colony of $5 \times 10^{7}$ (Yadav \& Chandra, 2014). Aluminum foil has airtight properties and its dark conditions support bacteria to stay awake compared to packaging that is directly exposed to sunlight so that it is faster to experience air shrinkage (Rahmawati, 2013). Charcoal-carrying materials have more pores as a place to live and have a high carbon content to support the survival of a microorganism (Surdianto et al., 2015). The bacteria's ability to survive is affected by environmental conditions that support it to multiply so that rhizo bacteria populations during storage are maintained. Viability affects the survival of microorganisms in storage by minimizing the air in the packaging, regulating environmental light, and incorporating antioxidant compounds (Cabello-Olmo et al., 2020)

\section{b. Water Absorption (\%)}

The treatment of husk charcoal has the highest absorption value in the first week of storage until the end of storage. Average water absorption is presented in Table 1.

Table 1: Average Water Absorption (\%) due to the treatment of the carrier material and packaging type for 16 weeks of storage.

\begin{tabular}{|c|c|c|c|c|c|}
\hline \multirow[t]{2}{*}{ Treatment } & \multicolumn{5}{|c|}{ Water Absorption (\%) at week: } \\
\hline & W0 & W10 & W12 & W14 & W16 \\
\hline \multicolumn{6}{|l|}{ Type of Carrier Material } \\
\hline Peat & $45.13 \mathrm{a}$ & $39.44 \mathrm{a}$ & $37,73 \mathrm{a}$ & $36,04 \mathrm{~b}$ & $32,49 \mathrm{a}$ \\
\hline Husk Charcoal & $64.64 \mathrm{c}$ & $63.11 \mathrm{c}$ & $61,43 \mathrm{c}$ & $59,13 \mathrm{~d}$ & $56,09 \mathrm{c}$ \\
\hline Husk Charcoal + Kaolin & $54.84 \mathrm{~b}$ & $47.43 \mathrm{~b}$ & $44,95 \mathrm{~b}$ & $42,36 \mathrm{c}$ & $39,43 \mathrm{~b}$ \\
\hline Peat + Kaolin & $43.30 \mathrm{a}$ & $36.23 \mathrm{a}$ & $32,90 \mathrm{a}$ & $30,68 \mathrm{a}$ & $28,33 \mathrm{a}$ \\
\hline Husk Charcoal + Peat + Kaolin & $47.41 \mathrm{a}$ & $37.00 \mathrm{a}$ & $33,30 \mathrm{a}$ & $31,41 \mathrm{ab}$ & $29,66 \mathrm{a}$ \\
\hline \multicolumn{6}{|l|}{ Type of Packaging } \\
\hline Plastic & $52.04 \mathrm{a}$ & $44,53 \mathrm{a}$ & $41,62 \mathrm{a}$ & $39,68 \mathrm{a}$ & $36,37 \mathrm{a}$ \\
\hline Aluminium Foil & $50.09 \mathrm{a}$ & $44,75 \mathrm{a}$ & $42,50 \mathrm{a}$ & $40,16 \mathrm{a}$ & $38,04 \mathrm{a}$ \\
\hline
\end{tabular}

Table 1 show that the highest percentage value of the carrier material type indicates high absorption. Absorption in granule fertilizer with huskcharcoal carrier material is higher than peat carrier material with adhesive-free material and has a low absorption value, namely peat and kaolin carrier material. The high water absorption in the treatment of husk charcoal carrier materials indicates the absorption percentage value at the beginning of storage of $64.64 \%$ and the 
International Journal of Agriculture and Environmental Research

ISSN: 2455-6939

Volume: 07, Issue: 05 "September-October 2021"

end of storage or the 16th week of storage which is $56.09 \%$. Maximum absorption occurs due to the nature of huskcharcoal that has tenuous pores so that it can bind to excess water. This condition is caused by the dominance of the fraction of huskcharcoal material that causes the touch surface area to become wide so that pore space is formed on the surface of the granule (Utari et al., 2015).

\section{c. Dispersion Time (minutes)}

Observation of dispersion time was carried out to determine the disintegration time of biofertilizers. The type of carrier material has a very significant effect on the dispersion time. Treatment of husk charcoal material had the fastest disintegration time in the early and final weeks of biological fertilizer storage. The average time of dispersion of biofertilizers is presented in Table 2

Table 2: Average dispersion time (minutes) due to the treatment of the carrier material and packaging type for 16 weeks of storage

\begin{tabular}{lcc}
\hline \multicolumn{1}{c}{ Treatment } & $\begin{array}{c}\text { Dispertion time (minutes) in the week to : } \\
\text { W16 }\end{array}$ & W16 \\
\hline Type of Carrier Material & & $48.83 \mathrm{~b}$ \\
\hline Peat & $59.07 \mathrm{bc}$ & $2.83 \mathrm{a}$ \\
Husk Charcoal & $13.63 \mathrm{a}$ & $11.53 \mathrm{a}$ \\
Husk Charcoal + Kaolin & $22.08 \mathrm{a}$ & $65.97 \mathrm{~b}$ \\
Peat + Kaolin & $77.51 \mathrm{c}$ & $12.26 \mathrm{a}$ \\
Husk Charcoal + Peat + Kaolin & $27.86 \mathrm{ab}$ & $31.64 \mathrm{a}$ \\
\hline Type of Packaging & & $24.93 \mathrm{a}$ \\
\hline Plastic & $38.71 \mathrm{a}$ & \\
Aluminium Foil & $41.34 \mathrm{a}$ & \\
\hline Description: The number followed by the same letter in the same column, shows no real difference according \\
to the Duncan Test 5\%
\end{tabular}

Based on Table 2, at the end of storage (week 16), it is seen that the treatment of husk charcoalcarrying materials has the fastest dispersion time in maintaining the viability of biofertilizers which is 2.83 minutes. The viability of biofertilizers is supported by a rapid dispersion time. The timing of the granule's destruction is seen with the cessation of $\mathrm{CO}_{2}$ production in the water. Granule fertilizer that has a fast time indicates that the physical properties of granules help direct absorption in plants when applying fertilizer. Bubbles produced when granule dissolution affects the time they disintegrate, the more $\mathrm{CO}_{2}$ is produced, the more bubbles the bubbles (Rahmawati et al., 2016). 


\section{d. Density value (grams/ml).}

The density value of each formula of biofertilizer carrier material was measured at the beginning of the study before storage, which is presented in Table 3.

Table 3: Density value (grams/ml) of biofertilizers in various carrier material formula

\begin{tabular}{lrrr}
\hline \multicolumn{1}{c}{ Treatment } & $\mathbf{m}(\mathbf{g})$ & $\mathbf{v}(\mathbf{m l})$ & $\boldsymbol{\rho}(\mathbf{g} / \mathbf{m l})$ \\
\hline Peat & 165 & 250 & 0.66 \\
Husk Charcoal & 96 & 250 & 0.38 \\
Husk Charcoal + Kaolin & 161 & 250 & 0.64 \\
Peat + Kaolin & 155 & 250 & 0.62 \\
Husk Charcoal + Peat + Kaolin & 140 & 250 & 0.56 \\
\hline
\end{tabular}

Description $: \rho=$ density value; $m=$ mass; $v=$ volume

Based on Table 3, the highest density value is found in a peat carrier material which is 0.66 grams $/ \mathrm{ml}$, followed by peat and kaolin mixture carrier material with a value of 0.62 grams/ml. The high-density value is because peat carriers have tighter granule constituent particles so that the air cavity owned by peat carriers is less (Utari et al., 2015). The material carrying huskcharcoal has the lowest value of 0.38 grams $/ \mathrm{ml}$. The low-density value of huskcharcoal-carrying materials allows water to transmit faster and increases permeability as the soil's ability to channel water is affected by soil density (Hazarika et al., 2019).

\section{e. Morphology of Granule Biofertilizer}

The morphology of granule biofertilizers was observed at the beginning of the study to see the differences of each fertilizer-carrying material in terms of color, structure, and texture of the soil and the extent of disintegration. According to Khairi (2019), texture observations became a benchmark in the granule morphological observations presented in Table 4. 
International Journal of Agriculture and Environmental Research

ISSN: 2455-6939

Volume: 07, Issue: 05 "September-October 2021"

Table 4: Morphology of granule biofertilizer physiologically

\begin{tabular}{|c|c|c|c|c|}
\hline Treatment & $\begin{array}{c}\text { Physiological } \\
\text { Pictures }\end{array}$ & Colour & Textured & $\begin{array}{l}\text { Crushed } \\
\text { pressure }\end{array}$ \\
\hline Peat & & $\begin{array}{l}\text { Dark } \\
\text { chocolate }\end{array}$ & $\begin{array}{lr}\text { Medium } & \\
\text { textured } & \text { soil } \\
\text { and a bit } \\
\text { rough }\end{array}$ & ++ \\
\hline Husk Charcoal & & Dark black & $\begin{array}{l}\text { Soil textured } \\
\text { smooth and } \\
\text { dust }\end{array}$ & + \\
\hline $\begin{array}{l}\text { Husk Charcoal + } \\
\text { Kaolin }\end{array}$ & & Dark grey & $\begin{array}{l}\text { Textured soil } \\
\text { but a bit rough }\end{array}$ & + \\
\hline Peat + Kaolin & & Light brown & $\begin{array}{l}\text { Coarse } \\
\text { textured soil } \\
\text { or sandy soil }\end{array}$ & +++ \\
\hline $\begin{array}{l}\text { Husk Charcoal + } \\
\text { Peat }+ \text { Kaolin }\end{array}$ & & Light gray & $\begin{array}{l}\text { Medium } \\
\text { textured soil. }\end{array}$ & ++ \\
\hline
\end{tabular}

Description: Crushed pressure $=+$ weak $;++$ Medium; +++ Strong

The storage of biofertilizers must be considered because it affects the quality and quantity of biofertilizers. Good storage supports microbes growing either on growing media or carrier 


\section{International Journal of Agriculture and Environmental Research}

ISSN: 2455-6939

Volume: 07, Issue: 05 "September-October 2021"

materials. Fertilizer conditions that are too wet can increase humidity so that contamination can increase. Based on research conducted, the fertilizer that has been dried is packaged and sealed to close air access from the outside or airtight conditions. Storage of biofertilizers is placed on enkas in a standing state. The viability of biofertilizers in carrier materials is affected by temperature and humidity so that it has a direct impact on the development and vitality of bacteria (Ahmed \& Khider, 2016).

The process of making granule fertilizer affects the small size of the granule. Granulators use the principle of centripetal work with the formation of granules due to the presence of spin force. The agglomeration process carried out by the granulator machine is fine particles that stick together to form larger granules (Hanna; et al., 2015). The carrying material has been inserted into granulator plates and given liquid fertilizer until the fertilizer is formed granules. The success of particle agglomeration depends on the adhesional force between particles that encourages granule formation as well as providing adequate mechanical strength to the product (Wullandari and Siregar, 2017). Kaolin additives are used as binding materials into one material in raw conditions to facilitate the formation of a granule (Effendi, 2016).

\section{CONCLUSION}

The formulation treatment of husk charcoal carrier material with aluminum foil packaging has the best results with a viability value of $\log _{10} 7.62 \mathrm{cfu} / \mathrm{grams}\left(4,58 \times 10^{7} \mathrm{cfu} / \mathrm{grams}\right)$. Formulation of husk charcoal-carrying material with aluminum foil packaging can maintain its viability related to the ability of bacteria in dark conditions and avoid air shrinkage. The husk charcoalcarrying material has the highest water absorption of $56.09 \%$, the fastest dispersion time is 2.83 minutes and the lowest bulk density value is 0.38 grams $/ \mathrm{ml}$. The formulation of the husk charcoal-carrying ingredient has deep black colour morphology and a weak texture.

\section{REFERENCES}

[1] Ahmed, A., \& Khider, A. K. (2016). Effect Of Storage Temperature, Duration And Types Of Biofertilizer Carriers On Survival And Numbers Of Bacterial Strains Bacillus Megaterium Var. Phosphaticum, Azotobacter Chroococcum, Rhizobium Leguminosarum And Transformant, Transconjugant B. Megateriu. June. Https://Doi.Org/10.17758/Eap.Eap816211

[2] Arpitha, P., \& Brahmaprakash, G. (2016). Evaluation Of Different Packaging Materials For Microbial Inoculants. Journal Of Pu, 10(2), 3909.

[3] Cabello-Olmo, M., Oneca, M., Torre, P., Díaz, J. V., Encio, I. J., Barajas, M., \& Araña, M. (2020). Influence Of Storage Temperature And Packaging On Bacteria And Yeast Viability In A Plant-Based Fermented Food. Foods, 9(3). 
International Journal of Agriculture and Environmental Research

ISSN: 2455-6939

Volume: 07, Issue: 05 "September-October 2021"

Https://Doi.Org/10.3390/Foods9030302

[4] Effendi, M. D. (2016). Analisa Kimia Dan Identifikasi Mutu Kaolin Bangka Berdasarkan Syarat Mutu Kaolin Sebagai Bahan Baku Keramik Halus. Badan Pengkajian Dan Penerapan Teknologi (BPPT), June 2004. Https://Doi.Org/10.13140/RG.2.1.3194.8408

[5] Firdausi, N., Muslihatin, W., \& Nurhidayati, T. (2016). Pengaruh Kombinasi Media Pembawa Pupuk Hayati Bakteri Penambat Nitrogen Tehadap pH Dan Unsur Hara Nitrogen Dalam Tanah. Jurnal Sains Dan Seni ITS, 5(2), 1-4.

[6] Hazarika, H., Devnita, R., Natalie Fitriatin, B., Fatimah Rosana, M., \& Arifin, M. (2019). Soil Chemical, Physical And Biological Characteristics Of Andisols As Affected By The Amelioration Of Steel Slag And Rice Husk Bokashi. Academic Journal Of Science, 09(01), 231-239.

[7] Jha, C. K., \& Saraf, M. (2014). Plant Growth Promoting Rhizobacteria. Journal Of Plant Nutrition, 37(14), 2227-2235. Https://Doi.Org/10.1080/01904167.2014.920384

[8] Peraturan Menteri Pertanian No. 70/Permentan/SR.140/10/2011 tentang Pupuk Organik, Pupuk Hayati dan Pembenah Tanah. Jakarta.

[9] Khairi, Yuhan Al. 2019. Struktur dan Tekstur Tanah - Pengertian, Jenis, hingga Fungsinya. https://www.99.co/id/panduan/struktur-dan-tekstur-tanah-pengertian-jenishingga-fungsinya. 15 Juli 2021

[10] Rahayu, F. P. (2017). The Viability Of Azotobacter In Biofertilizer Granular. 1-86.

[11] Rahmawati, F. (2013). Pengemasan Dan Pelabelan. Biomaterials, 29(34), 4471-4480.

[12] Rahmawati, I. F., Pribadi, P., \& Hidayat, I. W. (2016). Formulasi Dan Evaluasi Granul Effervescent Ekstrak Daun Binahong (Anredera Cordifolia (Tenore) Steen.). Pharmaciana, 6(2). Https://Doi.Org/10.12928/Pharmaciana.V6i2.4078

[13] Surdianto, Y., Sutrisna, N., Basuno, \& Solihin. (2015). Panduan Teknis Cara Membuat Arang Sekam Padi. In Balai Pengkajian Teknologi Pertanian (BPTP) Jawa Barat.

[14] Tomasiewicz, D. M., Hotchkiss, D. K., Reinbold, G. W., Jr, R. B. R., \& Hartman, P. A. (2021). The Most Suitable Number Of Colonies On Plates For Counting. Journal Of Food Protection, 43(4), 282-286.

[15] Utari, N. W. A., Tamrin, \& Triyono, S. (2015). Kajian Karakteristik Fisik Pupuk Organik Granul Dengan Dua Jenis Bahan Perekat (The Study Of Physical Characteristics Of Granular Organic Fertilizer With Two Adhesives). Jurnal Teknik Pertanian Lampungvol, 3(3), 267-274.

[16] Wardhani, A. K., Uktolseja, J. L. ., \& Djohan. (2020). Identifikasi Morfologi Dan Pertumbuhan Bakteri Padapada Cairan Terfermentasi Silase Pakan Ikan. Artikel Pemakalah Paralel, P-ISSN: 2527-533X, 411-419.

[17] Wullandari, P., \& Siregar, A. (2017). Pembuatan Pupuk Organik Granul Dari Tepung Rumput Laut Sargassum Sp . Ratio Optimization Of Water And Other Ingredients In The 
International Journal of Agriculture and Environmental Research

ISSN: 2455-6939

Volume: 07, Issue: 05 "September-October 2021"

Production Of Organic Granules Fertilizer From Sargassum Sp . Flour. 31-42.

[18] Yadav, A. K., \& Chandra, K. (2014). Mass Production And Quality Control Of Microbial Inoculants. Proceedings Of The Indian National Science Academy, 80(2), 483-489. Https://Doi.Org/10.16943/Ptinsa/2014/V80i2/5

[19] Zulfatul Hanna; Apriliani, A. D., \& Sutikno, J. P. (2015). Studi Awal Desain Pabrik Pupuk Organik Granul Dari Organic Waste. Jurnal Teknik, 4(2), F153-F156. 